\title{
CHARACTERISATION OF FIVE SIDEROPHORE PRODUCING ACTINOMYCETES FROM SOIL SAMPLES AND THE USE OF ANTIBIOTIC RESISTANCE TO DIFFERENTIATE THE ISOLATES
}

\section{ISMINI NAKOUTI AND GLYN HOBBS*}

School of Pharmacy and Biomolecular Sciences, Liverpool John Moores University, Byrom Street, Liverpool, L3 3AF, UK.

${ }^{*}$ Corresponding Author: Email- g.hobbs@livjm.ac.uk

Received: February 07, 2012; Accepted: April 03, 2012

\begin{abstract}
Organisms were isolated on their basis of survival in an iron-limited environment. The survivors of this treatment were largely actinomycetes. Of the viable cultures, most were found to produce siderophore like compounds. The most prolific producers as assessed by the Chromo Azuerol Sulphate assay were further characterised and found to belong to the genus Streptomyces. Attempts to taxonomically characterise these organisms illustrated the conserved nature of the 16S rRNA gene in this group of organisms. Physiological characterisation was undertaken and it was found that the resistance of these organisms to a range of antibiotics proved to be a useful discriminating factor .
\end{abstract}

Key words- Actinomycetes, iron chelation, siderophores, soil, streptomycetes, classification, resistance

Citation: Ismini Nakouti and Glyn Hobbs (2012) Characterisation of Five Siderophore Producing Actinomycetes from Soil Samples and the Use of Antibiotic Resistance to Differentiate the Isolates. International Journal of Agriculture Sciences, ISSN: 0975-3710 \& E-ISSN: 09759107, Volume 4, Issue 3, pp-202-206.

Copyright: Copyright@2012 Ismini Nakouti and Glyn Hobbs. This is an open-access article distributed under the terms of the Creative Commons Attribution License, which permits unrestricted use, distribution, and reproduction in any medium, provided the original author and source are credited.

\section{Introduction}

Iron is a fundamental element to microbial nature. Due to the evolution of the di-oxygen atmosphere in the earth's terrestrial environment, iron forms insoluble, bio unavailable ferric moieties at physiological $\mathrm{pH}$ [1]. In order to capture iron microorganisms have developed specific mechanisms involving the formation of siderophores [2]. The latter are low molecular weight compounds synthesised under iron starvation; they are produced extracellularly to bind iron and other ions forming a metal-siderophore complex. These complexes are then bound by the cells and transported intracellularly [3-6].

The actinomycetes are notorious environmental scavengers and have well-developed processes to capture ions in conditions depleted of elements; they are therefore an ideal target group for exploitation in ion binding technology [7-9]. Here we report the characterisation of four siderophore producing actinomycetes.

The taxonomy of streptomycetes has been extensively studied by many groups and comprehensive reviews are available in the literature [10-12]. Modern molecular taxonomical approaches involve the sequence analysis of the 16S rRNA gene, a particularly powerful tool in the classification of streptomycetes. Although $16 \mathrm{~S}$ rRNA is a highly conserved area of the genome, it contains enough variations to allow us to investigate relationships at the genus, species and strain levels. Nevertheless it can be misleading due to intragenic variation, which highlights the need of genotypic and phenotypic observations [12]. One possible discriminatory factor is the resistance profile to antibiotics. This article describes data that uses antibiotic resistance to differentiate the siderophore producing isolates.

\section{Materials and Methods \\ Purification of actinomycetes from soil:}

A soil sample $(1 \mathrm{~g})$ was suspended in $100 \mathrm{ml}$ of sterile distilled water and incubated $40^{\circ} \mathrm{C}$ for 24 hours. Actinomycetes were isolated from the soil suspension using a dilution plate technique on starch-casein agar (1.0 of starch, $0.4 \mathrm{~g}$ of casein, $0.5 \mathrm{~g}$ of $\mathrm{KNO}_{3}, 0.1 \mathrm{~g}$ of $\mathrm{MgPO}_{4}, 0.2 \mathrm{~g}$ of $\mathrm{K}_{2} \mathrm{HPO}_{4}, 0.1 \mathrm{~g}$ of $\mathrm{CaCO}_{3}$ and $15 \mathrm{~g}$ of agar per litre of distilled water $\left[\mathrm{dH}_{2} \mathrm{O}\right]$ ) supplemented with 150 
mM 2,2'-dipyridyl (DIP). The agar plates were incubated at $27^{\circ} \mathrm{C}$ for up to four weeks. Selective colonies were further sub-cultured and pure actinomycetes were isolated [13].

\section{Siderophore production}

Siderophore production was confirmed using the Chromo Azuerol Sulphate (CAS) assay (Renshaw et al. 2003). Arnow's [14] and Atkin's [15] assays confirmed the presence of a catecholic and hydroxamate compounds respectively.

\section{Actinomycete characterisation}

Actinomycete colonies were characterised according to Bergey's Manual of Systematic Bacteriology [16]; specific characteristics were observed by light and scanning electron microscopy.

The ability of the organisms to utilise different nutrient sources was tested using the SF-N2 (OXOID) and GP2 (OXOID) Biolog Microplates.

Antibiotic resistance of the strains was examined using MASTRINGS (Mast Diagnostics) and susceptibility discs (OXOID) performing the disc diffusion test. The model streptomycete, Streptomyces coelicolor (S. coelicolor) was also included in this study for comparison.

The strains were also tested for their ability to grow and sporulate on a range of liquid or solid media, including yeast extract-malt extract (YEME), Mannitol-Soya bean flower (MS), Muller-Hinton (MH), MH glucose, MH fructose and starch-casein agar [13].

\section{S rRNA amplification and taxonomic analysis}

Genomic DNA was extracted using the 'Kirby mix procedure' [13]. Amplification of the $16 \mathrm{~S}$ sequences were performed according to Rintala et al. 2001 [17].

The amplified products were purified using the QIAquick ${ }^{R}$ PCR purification kit (50) [Qiagen] and sent to LarkTM Technologies, Inc (United Kingdom) according to their requirements.

Pairwise sequence comparisons and retrieval of homologous sequences were conducted by the NCBI BLAST database (available online- http://www.ncbi.nih.gov/). Similar sequences, including an outgroup (ancestral sequence), were multiple aligned by BioEdit sequence alignment Editor 7.0.4.1 (Copyright 1997-2005, Hall, 1999). Taxonomic analysis was performed by the ClustalX software, version 1.83 and Bootstrap confidence values (1000) were provided by the Neighbour- Joining (NJ) algorithm. Finally the phylogenetic tree was presented using TreeView (Win 32) 1.6.6 (Copyright 2001) by Roderic. D. M. Page, available online: http:// taxonomy.zoology.gla.ac.uk/rod/rod.html).

\section{Results}

\section{Strain isolation}

In an attempt to identify novel siderophore compounds we have isolated and purified 154 cultures from soil samples collected in Thailand (Tak province). The majority of strains are considered to be members of actinomycetes on the evidence of phenotypic examination. All the isolates were grown on starch-casein agar containing $150 \mathrm{mM}$ DIP. This concentration of DIP was chosen as it reduced the number of surviving actinomycete colonies by approximately $99 \%$. The remaining $1 \%$ was thought to be likely to have physiological attributes that enabled them to survive iron limitation. Twenty-two strains were confirmed CAS-assay positive with five strains (23F, 31B, 31C, 33D and 29C- GenBank accession numbers EF585403 - EF585407) exhibiting prolific siderophore production. Liquid based assays were conducted on culture supernatants in order to categorise the siderophore producers. The results classified the strains 31B, 31C, 33D and 29C as catechol producers, whereas $23 \mathrm{~F}$ was categorised as a hydroxamate synthesiser.

16S rRNA gene sequence analysis and phylogenetic studies 16S rRNA gene sequence analysis was carried out to elucidate the taxonomic position of the isolates. Almost complete 16S rRNA sequences of the representatives were determined following the isolation of genomic DNA and sequencing of the amplified genes. The strains' phylogenetic positions are reported in figure 1. The levels of 16S rRNA sequence similarities between the isolates and actinomycetes species ranged from $97-99 \%$, confirming that the strains are members of the family, mainly streptomycetes.

The high percentage similarity values amongst species of the same genus are very common due to the highly conserved nature of the gene. For example although Streptomyces macrosporus and Streptomyces megasporus share $98 \%$ similarities, they are clearly different on their phenotypic characterisation. A second paradigm includes Streptomyces thermocarboxydovorans (S. thermocarboxydovorans) and Streptomyces thermodiastaticus (99 $\%$ ) or S. thermocarboxydovorans and S. thermoviolaceous (98\%) [18]. Moreover Amycolatopsis albidoflavus share $97.4 \%$ similarities with Amycolatopsis azurea and Amycolatopsis orientalis [19].

\section{Characterisation of the strains}

All the streptomycete stains were further investigated in order to determine their morphological, physiological, growth and biochemical characteristics. Their ability to use a variety of nutrient compounds is described in Table 1.

\section{Table 1- Nutrient utilisation of the five isolates}

\begin{tabular}{llllll} 
Nutrient utilisation of: & \multicolumn{5}{c}{ Isolates } \\
(Measured using the Biolog system) & \multicolumn{5}{c}{} \\
a-Cyclodextrin & $23 \mathrm{~F}$ & $29 \mathrm{C}$ & $31 \mathrm{~B}$ & $31 \mathrm{C}$ & $33 \mathrm{D}$ \\
b-Cyclodextrin & + & - & + & - & + \\
Dextrin & + & - & + & + & + \\
Glycogen & + & - & + & + & + \\
Inulin & + & - & + & + & + \\
Mannan & + & - & + & + & + \\
Tween 40 & + & - & - & - & + \\
Tween 80 & + & + & + & + & + \\
N-Acetyl-D-Glucosamine & - & + & - & - & + \\
N-Acetyl-b-D-Mannosamine & + & - & - & - & + \\
Amygdalin & + & - & + & - & + \\
L-Arabinose & - & - & - & - & - \\
D-Arabitol & + & - & + & - & + \\
Arbutin & - & - & + & - & - \\
D-Cellobiose & + & - & + & - & + \\
D-Fructose & + & - & + & - & + \\
L-Fucose & + & + & + & - & + \\
D-Galactose & + & - & + & + & + \\
D-Galacturonic Acid & - & - & + & - & + \\
Gentiobiose & - & - & + & - & + \\
D-Gluconic Acid & - & - & + & - & + \\
a-D-Glucose & + & + & + & + & + \\
m-Inositol & + & + & - & - & + \\
a-D-Lactose & + & - & + & + & + \\
Lactulose & - & - & - & - & + \\
Maltose & - & - & - & - & + \\
Maltotriose & - & - & + & - & - \\
\hline & - & - & + & - & - \\
\hline
\end{tabular}


Table 1 Continue

\begin{tabular}{|c|c|c|c|c|c|}
\hline D-Mannitol & - & - & + & - & - \\
\hline D-Mannose & - & - & - & - & - \\
\hline D-Melezitose & - & - & + & - & - \\
\hline D-Melbiose & + & - & + & + & + \\
\hline a-Methyl-D-Galactoside & - & - & + & - & + \\
\hline b-Methyl-D-Galactoside & - & - & - & - & - \\
\hline 3-Methyl Glucose & + & - & - & + & + \\
\hline a-Methyl-D-Glucoside & + & - & + & + & - \\
\hline b-Methyl-D-Glucoside & - & - & - & + & - \\
\hline a-Methyl-D-Mannoside & - & - & - & + & + \\
\hline Palatinose & + & - & + & + & + \\
\hline D-Psicose & - & - & + & - & - \\
\hline D-Raffinose & - & - & - & - & - \\
\hline L-Rahamnose & - & - & + & - & - \\
\hline D-Ribose & + & - & + & - & + \\
\hline Salicin & - & - & - & - & + \\
\hline Sedoheptulosan & - & - & - & - & -- \\
\hline D-Sorbitol & + & - & - & - & - \\
\hline Stachyose & + & - & + & + & + \\
\hline Sucrose & + & - & + & - & + \\
\hline D-Tagatose & + & - & - & - & + \\
\hline D-Trehalose & - & - & - & - & - \\
\hline Turanose & + & - & - & + & - \\
\hline Xylitol & - & - & - & - & - \\
\hline D-Xylose & - & - & - & - & - \\
\hline Acetic Acid & + & + & + & - & + \\
\hline a-Hydroxybutyric Acid & - & + & - & - & - \\
\hline b-Hydroxybutyric Acid & - & + & + & + & + \\
\hline g-Hydroxybutyric Acid & - & + & - & - & + \\
\hline p-Hydroxy-Phenylacetic Acid & - & - & - & - & - \\
\hline a-Ketoglutaric Acid & - & + & + & + & + \\
\hline a-Ketovaleric Acid & + & + & + & + & + \\
\hline Lactamide & + & - & + & + & + \\
\hline D-Lactic Acid Methyl Ester & - & - & + & - & + \\
\hline L-Lactic Acid & - & + & - & - & - \\
\hline D-Malic Acid & + & + & - & + & + \\
\hline L-Malic Acid & + & + & - & - & + \\
\hline Pyruvatic Acid Methyl Ester & + & + & + & + & - \\
\hline Succinic Acid Mono-methyl Ester & + & + & - & + & + \\
\hline Propionic Acid & + & + & + & + & + \\
\hline Pyruvic Acid & + & + & + & + & + \\
\hline Succinamic Acid & + & + & + & + & + \\
\hline Succinic Acid & + & + & - & + & + \\
\hline N-Acetyl-L-Glutamic Acid & + & - & - & - & + \\
\hline L-Alaminamide & - & + & + & + & + \\
\hline D-Alanine & - & + & - & + & + \\
\hline L-Alanine & + & + & - & + & + \\
\hline L-Alanyl-Glycine & - & + & + & _ & - \\
\hline L-lysine & + & + & + & + & + \\
\hline L-Asparagine & + & + & + & + & + \\
\hline L-Glutamic Acid & + & - & - & - & + \\
\hline Glycil-L-Glutamic Acid & - & + & - & - & - \\
\hline L-Pyroglutamic Acid & - & - & - & - & - \\
\hline L-Serine & + & - & + & + & - \\
\hline Putrescine & + & + & + & + & + \\
\hline 2,3-Butanediol & + & - & - & - & - \\
\hline Glycerol & - & - & + & - & - \\
\hline Adenosine & + & - & + & - & + \\
\hline 2'-Deoxy Adenosine & + & - & + & + & + \\
\hline Inosine & - & - & + & + & + \\
\hline Thymidine & + & - & + & + & + \\
\hline Uridine & - & - & + & - & - \\
\hline Adenosine-5'-Monophosphate & - & - & + & + & - \\
\hline Thymidine-5'-Monophosphate & - & - & + & + & - \\
\hline Uridine-5'-Monophosphate & - & - & - & - & - \\
\hline D-Fructose-6'-Phosphate & + & - & + & + & + \\
\hline a-D-Glucose-1-Phosphate & - & - & - & - & + \\
\hline D-Glucose-6'-Phosphate & + & - & - & - & + \\
\hline D-L-a-Glycerol Phosphate & + & - & - & - & + \\
\hline
\end{tabular}

Table 1- Nutrient utilisation of strains 29C (GenBank accession number EF585407), 33D (GenBank accession number EF585406), 31B (GenBank accession number EF585404), 31C (GenBank accession number EF585405) and 23F (GenBank accession number EF585403).

\section{Description of 29C (GenBank accession number EF585407):}

Strain $29 \mathrm{C}$ is a Gram-positive, aerobic, white mycelia-forming organism that undergoes the typical streptomycete life cycle resulting in pink spirales spores. The spore surface was found to be smooth and this stage of the life cycle was only ever observed on starch-casein and YEME solid media. It did not sporulate on MS (Manitol-Soya agar) agar but it produced a diffusible pigment. It tolerated $150 \mathrm{mM}$ DIP and in starch-casein media it overproduced a very 'powerful' catechol that formed strong ferric complexes. It was found to produce a bactericidal agent against

Bacillus subtilis (B. subtilis) and Candida albicans ( $C$. albicans) under all conditions tested. In our hands it grew best in starchcasein media, $\mathrm{pH} 7.5$ at $30^{\circ} \mathrm{C}$.

\section{Description of 33D (GenBank accession number EF585406):}

It is a Gram positive, aerobic streptomycete species producing brown spirales spores. It grew rapidly on MS, starch-casein, yeast extract-malt extract (YEME) and slightly slower on Muller-HintonFructose (MHF) or Muller-Hinton-Glucose (MHG). It was highly pigmented when grown on YEME and MS; nevertheless it did not sporulate well in the former cultivation media.

It grew poorly on MS, $\mathrm{pH} 5$, and appeared to be unstable at $\mathrm{pH} 7$. Optimum growth was on MS, pH 8 at $30^{\circ} \mathrm{C}$. It produced an antimicrobial against $B$. subtilis and was found to be extremely tolerant to DIP $(600 \mathrm{mM})$, suggesting a well-adapted organism in its environment. It is worth noting that it overproduced a catechol on starch-casein agar, whereas it synthesised only a small amount of the specific siderophore on MS

Description of 31C (GenBank accession number EF585405): $31 \mathrm{C}$ is a Gram positive, aerobic streptomycete producing rectiflexible white/grey spore chains. This strain only produced substrate mycelia on MHG or MHF agar, and on YEME solid media appeared to be extremely unstable forming heterologous colonies. It grew on MS agar, $\mathrm{pH} 5-7$, with a preference for $\mathrm{pH} 7$ where it only formed aerial mycelia. It solely sporulated on starch-casein media with an optimum growth at $\mathrm{pH} 7.5$ at $30^{\circ} \mathrm{C}$. It posed antibiosis against both $B$. subtilis and $C$. albicans but only in media where catechol production is negligible.

Description of 31B (GenBank accession number EF585404): This isolate is a Gram positive, aerobic streptomycete producing rectiflexible spores. It was apparent that $31 \mathrm{~B}$ had fastidious growth requirements and appeared unstable in our hands. It was also evident that its growth rate was extremely slow with a preference

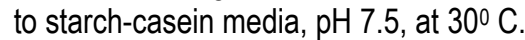

\section{Description of 23F (GenBank accession number EF585403):}

This strain is a Gram positive, aerobic actinomycete, which belongs to Streptomyces genus, and produced spores with an ornamented surface (spiny).

The organism was well adapted to its environment tolerating up to $600 \mathrm{mM}$ DIP and growing in a range of $\mathrm{pH}(5-8)$ and temperature 
(280 C- $370 \mathrm{C})$ conditions. It grew quickly on MS (3 days) agar, nevertheless much slower in starch-casein medium (approximately 10 days). It did not sporulate on YEME agar and on MHG and its optimum growth conditions involved cultivation on MS or starch-casein, $\mathrm{pH} 7$, at $370 \mathrm{C}$.

\section{Antibiograms}

Antibiotic resistance data offer valuable information in terms of strain characterisation and identification (Table 2). In the specific small-scale experiment 14 out of 24 antibiotics demonstrated different patterns amongst the streptomycetes. Careful examination of the data revealed specific profiles for Streptomyces coelicolor (S. coelicolor) and strains 23F, 29C and 31B. For example sensitivity to amoxicillin, cefuroxim or oxaxillin was a unique characteristic of isolate $29 \mathrm{C}$. Stain $31 \mathrm{~B}$ was the only candidate that was resistant to vancomycin. A combination of growth in the presence of erythromycin and levofloxacin differentiated strain 23F from S. coelicolor. Culture 33D could be identifiable by its sensitivity against ampicillin and vancomycin. Finally $S$. coelicolor demonstrated a distinctive pattern of tetracycline $(10 \mu \mathrm{g})$ and erythromycin resistance.

Table 2-Antibiograms of the siderophore producing strains. S. coelicolor is included as a reference

\begin{tabular}{|c|c|c|c|c|c|c|}
\hline \multirow{2}{*}{$\begin{array}{l}\text { Antibiograms } \\
\text { Resistant to: }\end{array}$} & \multicolumn{6}{|c|}{ Isolates } \\
\hline & $23 \mathrm{~F}$ & $29 \mathrm{C}$ & $31 \mathrm{~B}$ & $31 \mathrm{C}$ & 33D & $\begin{array}{l}\text { S. coeli- } \\
\text { color }\end{array}$ \\
\hline Amoxycillin 2mg & + & - & + & + & + & + \\
\hline $\begin{array}{l}\text { Amoxycillin/clavulanic } \\
\text { acid 3mg }\end{array}$ & + & + & + & + & + & + \\
\hline Ampicillin 25 mg & + & + & - & + & - & + \\
\hline Cefotaxime sodium $5 \mathrm{mg}$ & + & + & + & + & + & + \\
\hline Cefuroxime $5 \mathrm{mg}$ & + & - & + & + & + & + \\
\hline Cephalexin $30 \mathrm{mg}$ & + & + & + & + & + & + \\
\hline Chloramphenicol $50 \mathrm{mg}$ & - & + & + & - & - & - \\
\hline Ciprofloxacin $1 \mathrm{mg}$ & + & - & + & + & + & - \\
\hline Colistin sulphate $100 \mathrm{mg}$ & - & - & - & - & - & - \\
\hline Erythromycin $5 \mathrm{mg}$ & + & - & - & - & - & + \\
\hline Gentramicin $10 \mathrm{mg}$ & - & - & - & - & - & - \\
\hline Kanamycin 30 mg & - & - & - & - & - & - \\
\hline Levofloxacin $1 \mathrm{mg}$ & + & - & + & + & + & - \\
\hline Nalidixic Acid 30 mg & + & + & + & + & + & + \\
\hline Netilmicin $10 \mathrm{mg}$ & - & - & - & - & - & - \\
\hline Nitrofurantoin 50 mg & + & + & + & + & + & + \\
\hline Nitrofurantoin $200 \mathrm{mg}$ & + & - & - & + & + & + \\
\hline Oxaxillin $1 \mathrm{mg}$ & + & - & + & + & + & + \\
\hline Penicillin G 1 unit & + & + & + & + & + & + \\
\hline $\begin{array}{l}\text { Piperacillin/tazobactam } \\
85 \mathrm{mg}\end{array}$ & + & + & - & - & + & + \\
\hline Spectinomycin 25 mg & + & - & - & + & + & + \\
\hline Streptomycin $25 \mathrm{mg}$ & - & - & - & - & - & - \\
\hline Tetracycline $10 \mathrm{mg}$ & - & - & - & + & + & + \\
\hline Tetracycline $100 \mathrm{mg}$ & - & - & - & - & - & - \\
\hline Trimethoprim $2.5 \mathrm{mg}$ & + & + & - & + & + & + \\
\hline Vancomycin $5 \mathrm{mg}$ & - & - & + & - & - & - \\
\hline
\end{tabular}

Table 2- Antibiograms of the siderophore producing isolates $29 \mathrm{C}$ (GenBank accession number EF585407), 33D (GenBank accession number EF585406), 31B (GenBank accession number EF585404), 31C (GenBank accession number EF585405) and 23F (GenBank accession number EF585403). S.coelicolor, the model streptomycete, is included as a reference organism.

\section{Discussion}

It is anticipated that the isolation and characterisation of new actinomycetes might lead to novel siderophores of significant pharmaceutical interest. Although $16 \mathrm{~S} \mathrm{rRNA}$ analysis is a very powerful tool in phylogenetic relationships, it does not provide enough evidence for classification of closely related species. Therefore a 'universal' approach, which will include the combination of modern molecular approaches with a number of morphological, physiological and biochemical characteristics, will facilitate the understanding of the genotypic and phenotypic behaviour of these precocious siderophore producers. Antibiotic resistance data provide useful information on the nature of the cells. A report by Hopwood reaffirms the importance of actinomycetes as a major reservoir of antibiotic resistance genes [20]. Clearly these characteristics can be a useful way of classifying strains. This could be a valuable evolutionary route to differentiate strains within a population. Given the fact that Streptomyces species have been found to have the capacity to produce multiple "antimicrobial" compounds $[9,21]$ and hence the ability to be resistant to these compounds, it will be interesting to develop a resistance fingerprint system for strains and to revisit phylogenetic analysis in the light of this information.

\section{References}

[1] Wandersman C. and Delepelaire P. (2004) Annu Rev Microbiol 58, 611-647.

[2] Gunter K., Toupet C. and Schupp T. (1993) J Bacteriol 175 , 3295-3302.

[3] Neilands J.B. (1995) J Biol Chem 270, 26723-26726.

[4] Kalinowski B.E., Liermann L.J., Givens S. and Brantley S.L. (2000) Chem Geol 169, 357-370.

[5] John S.G., Christy E., Ruggiero L.E., Tung S. and Neu M.P. (2001) Environ Sci Techol 35, 2942-2948.

[6] Rodriquez M.G. and Smith I. (2003) Molecul Microbiol 47, 1485-1495.

[7] Meiwes J., Fiedler H.P., zahner H., Konetschny-Rapp S. and Jung G. (1990) Appl Microbiol Biotechnol 32, 505-510.

[8] Challis G.L. and Ravel J. (2000) FEMS Microbiol lett 187, 111114.

[9] Bentley S.D., Chater K.F., Cerdeno-Tarraga A.M., Challis G.L., Thomson N.R., James K.D., Harris D.E., Quail M.A., Kieser H., Harper D., Bateman A., Brown S., Chandra G., Chen C.W., Colllins M., Cronin A., Fraser A., Goble A., Hilalgo J., Hornsby T., Howarth S., Huang C.H., Kieser T., Larke L., Murphy L., Oliver K., O'Neil S., Robbinowitsch E., Rajandream M.A., Rutherford B.G., Rutter S., Seeger K., Saunders D., Sharp S., Squares S., Taylor K., Warren T., Wietzorrek A., Woodward J., Barrell B.G., Parkhill J. and Hopwood D.A. (2002) Nature 417, 141-147.

[10]Williams S.T., Goodfellow M., Alderson G., Wellington E.M.H., Sneath P.H.A. and Sackin M.J. (1983) J Gen Microbiol 129, 1743-1813.

[11]Williams S.T., Goodfellow M., Wellington E.M.H., Vickers J.C., Alderson G., Sneath P.H.A, Sackin M.J. and Mortimer A.M. (1983) J Gen Microbiol 129, 1815-1830.

[12]Anderson A.S. and Wellington E.M.H. (2001) Int J Syst Evol Microbiol 51, 787-814.

[13]Kieser T., Bibb M.J., Buttner M.J., Chater K.F. and Hopwood D.A. (2000) Streptomyces genetics, 8, 168-169 \& 342-343. 
The John Innes Foundation, Norwich.

[14]Arnow L.E. (1937) J Biol Chem 118, 531-537.

[15]Atkin C.L., Neilands J.B. and Phaff H.J. (1970) J Bacteriol 103, $722-733$.

[16]Locci R. (1989) Streptomyces and related Genera. In Bergey's Manual of Systematic Bacteriology ed Williams Wikins Company, Baltimore. 2451-1508.

[17]Rintala H., Nevalaines A., Ronka E. and Suutari M. (2001) Mol Cell Probes 15, 337-347.
[18]Kim C., Walter Lorenz W., Hoopes J.T. and Dean F.F.D. (2001) J Bacteriol 183, 4866-4875.

[19]Lee S.D. and Hah Y.C. (2001) Int J Syst Evol Microbiol 51, 645-650.

[20]Hopwood D.A. (2007) Mol Microbiol 63, 937-940.

[21]Omura S., Ikeda H., Ishikawa J., Hanamoto A., Takahashi C., Shinose M., Takahashi Y., Horikawa H., Nakazawa H., Osonoe T., Kikuchi H., Shiba T., Sakaki Y. and Hattori M. (2001) Proc Natl Acad Sci USA 98, 12215-12220.

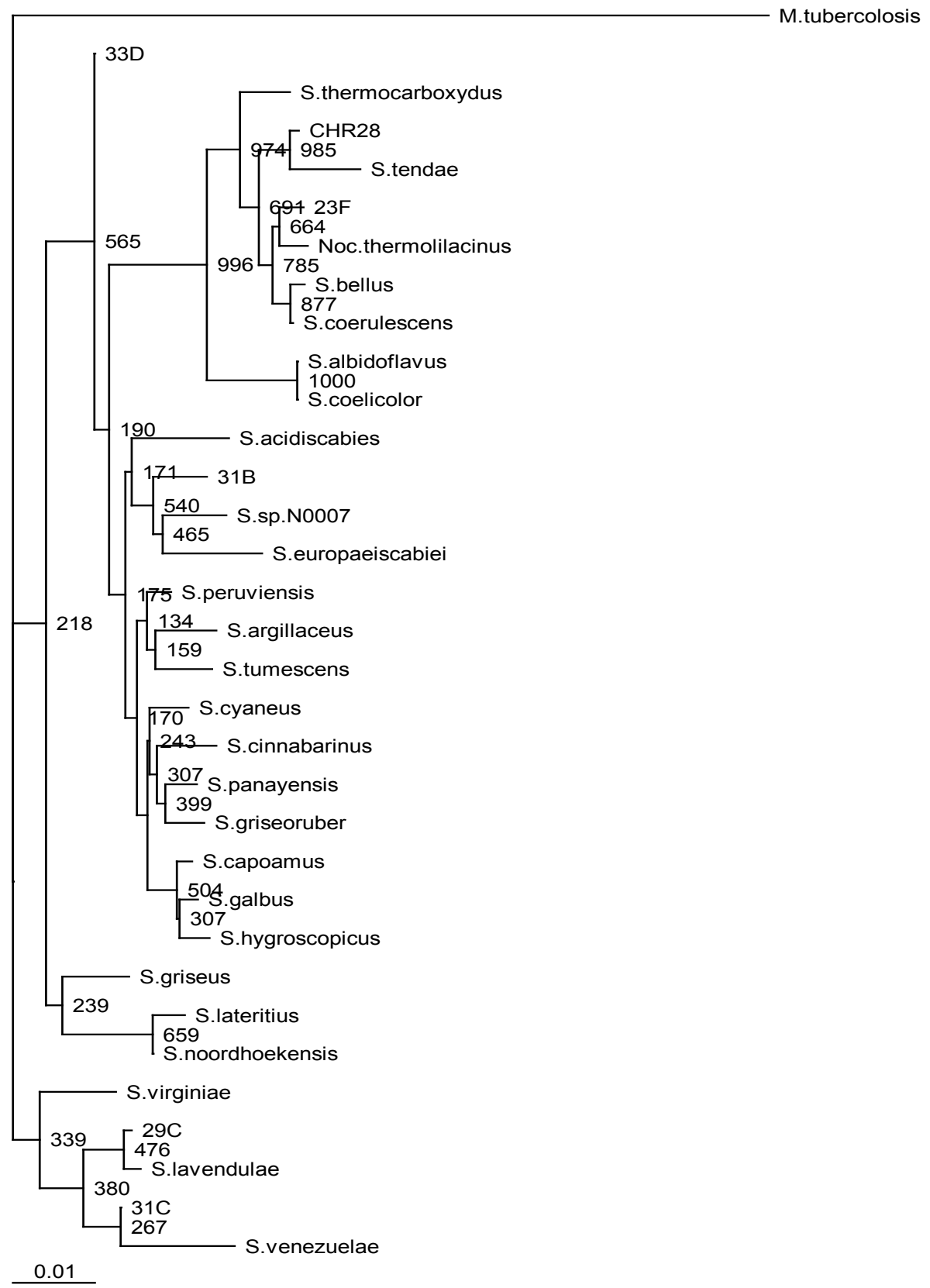

Fig. 1- Phylogenetic relationships of the isolates and related Actinomycetes based on the 16S rRNA sequence analysis. The tree is bootstrapped by 1000 times by Neighbour-Joining (N-J). M. tuberculosis was employed as an outgroup 